\title{
Внезапная сердечная смерть у спортсменов
}

\author{
УДК 796.015.11-055.206
}

\section{А. П. Ландырь}

Клиника спортивной медицины и реабилитации Тартуского университета, Тарту, Эстония

Резюме. Раптова серцева смерть (РСС) спортсмена є серйозною медичною і соціальною проблемою, оскільки зустрічається в молодому віці і стає трагедією для спортсмена, його сім'ї і тренера. Мета. Надання спортивним лікарям сучасної інформації про частоту розвитку і причини ВСС, про фактори, що сприяють їх розвитку, про методи діагностики захворювань і станів, які призводять до розвитку РСС, а також про заходи їх профілактики.

Результати. Наведено діагностичні ЕКГ-ознаки гіпертрофічної кардіоміопатії, міокардиту, аритмогенної дисплазії правого шлуночка, аномалій або атеросклерозу коронарних артерій, дилатаційної кардіоміопатії, які призводять до розвитку РСС, що дозволяє вжити заходів на самих ранніх етапах розвитку процесу. У процесі тренувань і змагань необхідно також враховувати вплив на спортсменів зіткнень із суперниками і ударів снарядів (шайба, м'яч тощо), що призводить до струсу серця. Висновок. Необхідно звернути увагу на використання нечесними спортсменами допінгу різної спрямованості (анаболічних стероїдів, стимуляторів, гормонів росту, наркотичних засобів і т.д.), які в стресових умовах змагань, у важких кліматичних умовах при передозуванні можуть привести до РСС.

Завданням спортивного лікаря є виявлення у спортсменів початкових ознак патології, збір поглибленого анамнезу, проведення діагностичних заходів, постановка діагнозу, вжиття заходів з лікування та запобігання розвитку процесу.

Ключові слова: раптова серцева смерть, ЕКГ-діагностика, гіпертрофічна кардіоміопатія, міокардит, аномалії коронарних артерій.

\section{Sudden cardiac death in athletes}

\section{A. P. Landyr}

Clinic for Sports Medicine and Rehabilitation of the University of Tartu, Estonia, Tartu

Abstract. Sudden cardiac death (SCD) in athletes is a serious medical and social problem, as it occurs at young age and becomes a tragedy for the athlete, the athlete's family and coach. Objective. The aim of the review was to present sports doctors with up to date information on the frequency and causes of the SCD, the factors influencing the occurrence of SCD, the methods for diagnosing diseases and conditions that lead to SCD and the methods of prevention. Results. The review presents diagnostic indices in ECG for hypertrophic cardiomyopathy, arrhythmogenic right ventricular dysplasia, anomalies of the coronary arteries, myocarditis, dilated cardiomyopathy and aterosclerosis of the coronary arteries that can lead to SCD, detection of which enables to take measures to prevent SCD at the earliest stages. The athletes may be subjected to physical impacts by the opponents and projectiles (ball, puck, etc.) both during training and competitive activities, which may cause cardiac concussion. Conclusion. It is also important to take note of the usage of the doping substances like anabolic steroids, stimulants, growth hormones, drugs, etc., which can cause SCD in case of severe stress during competition, severe climate or overdose. The objective of the sports doctor is to detect the early signs of the pathologies, collect the anamnesis, carry out diagnostics and to take measures to treat the illnesses and stop the processes that can lead to SCD.

Keywords: sudden cardiac death, diagnostic indices in ECG, hypertrophic cardiomyopathy, myocarditis, anomalies of the coronary arteries. 
Постановка проблемы. Внезапная сердечная смерть определяется как смерть, наступившая в результате неожиданно развившейся остановки кровообращения в результате нарушений ритма сердца, которая произошла в течение 24 ч от начала появления клинических симптомов при отсутствии внешних причин, которые сами по себе могли бы стать причиной смерти.

В средствах массовой информации время от времени появляются сообщения о внезапной смерти спортсмена. У родственников и общественности возникает вопрос, как вообще может произойти такое трагическое событие, как гибель молодого человека, здоровье которого многократно проверено при проведении ежегодной диспансеризации, имеющего многолетнюю подготовку в избранном виде спорта и успешно выступающего в соревнованиях. При этом у спортсменов в большинстве случаев внезапной сердечной смерти (ВСС) отмечается отсутствие какой-либо предшествующей клинической симптоматики. Внезапная сердечная смерть у спортсменов встречается редко, но вызывает широкий резонанс, поскольку становится катастрофой для спортсмена и шоком для семьи, врача и тренера

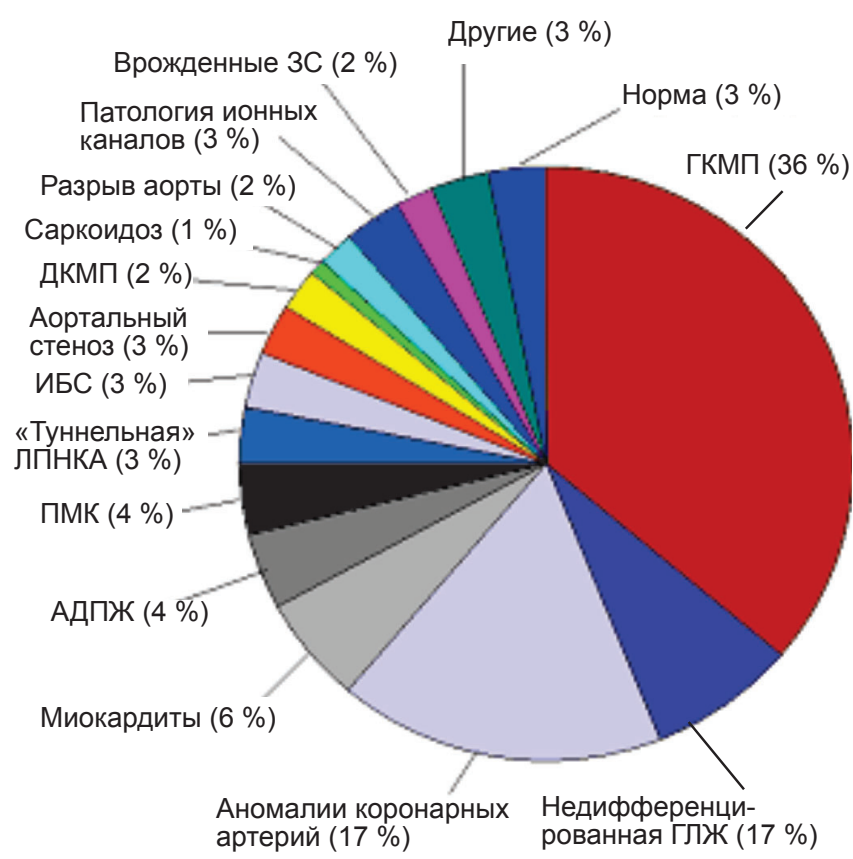

Рисунок 1 - Распределение причин внезапной сердечной смерти у молодых спортсменов [31]:

ГКМП - гипертрофическая кардиомиопатия; ГЛЖ гипертрофия левого желудочка; АДПЖ - аритмогенная дисплазия левого желудочка сердца; ПМК- пролапс митрального клапана; ЛПНКА - левая передняя нисходящая коронарная артерия; ИБС - ишемическая болезнь сердца; ДКМП - дилатационная кардиомиопатия; ЗС - заболевания сердца спортсмена, товарищей по команде, спонсоров, обслуживающего персонала и болельщиков. Тем более что общепризнано кардиозащитное действие двигательной активности и спорта, широко используемых в первичной и вторичной профилактике болезней сердца [1-3]. В то же время показано, что у спортсменов вероятность ВСС в 2,8 раза выше, чем у не занимающихся спортом в том же возрасте [4] в связи с воздействием целого ряда факторов (повышенная симпатостимуляция при фризической нагрузке, дегидратация, гипертермия, повышенная агрегация тромбоцитов, неблагоприятные условия внешней среды и т.д.) на систему кровообращения и организм в целом. Американские авторы [5] определили, что у спортсменов риск развития ВСС в 5 раз выше, чем у спортсменок, а по данным итальянских авторов [4] в 2,5 раза, что объясняется меньшими тренировочными и соревновательными фризическими нагрузками, более низкой конкуренцией, меньшим количеством соревнований и т.д. у обследованных ими спортсменок.

Цель исследования - предоставить спортивным врачам современную информацию о частоте развития и причинах ВСС. Проблеме внезапной сердечной смерти у спортсменов посвящены многие работы, которые отличаются методикой исследований, количеством пострадавших, клиническими и патологическими особенностями молодых спортсменов, скончавшихся на фоне полного здоровья [6-11].

Обширное исследование [7] причин внезапной сердечной смерти у 1435 молодых спортсменов выявило широкий спектр сердечно-сосудистых заболеваний, вызвавших внезапную смерть (рис. 1). Среди них четко выделяются гипертрофрическая кардиомиопатия, аномалии коронарных артерий и миокардиты, другие заболевания сердца имеют значительно более низкую частоту вызванных случаев внезапной смерти у обследованных спортсменов. Анализ случаев ВСС у спортсменов по возрасту выявил такую особенность: в возрасте до 35 лет в качестве причины смерти преобладают аритмии сердца, а в возрасте старше 35 лет - болезни коронарных артерий [7].

Профрилактика внезапной сердечной смерти включает комплекс мероприятий по первичной профилактике у спортсменов без эпизодов сердечного ареста в анамнезе или по вторичной профилактике у спортсменов, имеющих высокий риск развития ВСС или переживших сердечный арест. Если во многих странах Европы и Северной Америки еще только дискутируется [8-10, 12-16] необходимость регулярного об- 
следования спортсменов с целью профилактики врожденных и приобретенных заболеваний, способных вызвать внезапную сердечную смерть, то в постсоветских странах, имеющих более чем полувековую систему ежегодной диспансеризации юных и взрослых спортсменов, врачебно-педагогического контроля, медико-биологического обеспечения сборных команд страны, число таких случаев сведено к минимуму.

Результаты исследования и их обсуждение. Важнейшая роль в диагностике заболеваний, способных вызвать внезапную сердечную смерть, принадлежит электрокардиографической методике. При гипертрофичческой кардиомиопатии признаки нарушений на ЭКГ имеются в $90 \%$ случаев, при аритмогенной дисплазии правого желудочка - в 60-80 \%, при дилатационной кардиомиопатии и миокардите - в 30-60\% случаев [16].

Задачей спортивного врача является выявление характерных для этих заболеваний изменений на ЭКГ и анализ причин, вызвавших их возникновение, проведение дифференциального диагноза при аналогичных изменениях на ЭКГ при других заболеваниях, использование дополнительных методов исследования. По результатам обследования принимается решение о полном немедленном отстранении спортсмена от тренировочного процесса или о снижении тренировочной нагрузки в определенных пределах.

Патология ионных каналов (синдромы удлиненного и укороченного интервала QT, синдром Бругада, синдром электрической нестабильности кардиомиоцитов) и синдромы преждевременного возбуждения желудочков сердца (синдромы WPW и LGL), способные вызвать внезапную сердечную смерть у спортсменов, будут описаны в следующем обзоре. Ниже представлены диагностически значимые изменения на ЭКГ при заболеваниях миокарда у спортсменов, которые наиболее часто становились причиной внезапной сердечной смерти.

\section{Гипертрофическая кардиомиопатия}

Гипертрофрическая кардиомиопатия (ГКМП) является самой частой причиной (36\%), вызывающей внезапную смерть у молодых спортсменов, из-за развития фрибрилляции желудочков и остановки сердца $[6,7,17]$. При этом средние значения максимальной толщины стенки левого желудочка сердца составили $23 \pm 5$ мм, а массы сердца $521 \pm 113$ г $(6,18)$. Болезнь чаще выявляется у представителей скоростно-силовых видов спорта (спринтеров, штангистов, метателей и т.д.), тренировочный процесс которых направлен на увеличение мышечной массы скелетной мускулатуры и сопровождается сопутствующим увеличением массы миокарда, а также у спортсменов игровых видов спорта (баскетболистов, фрутболистов, хоккеистов и т.д.), у которых в процессе выполнения тренировочных и соревновательных нагрузок преобладают частые переключения скорости (start-stop sport), сопровождающиеся резким повышением симпатотонуса и вызывающие неоднородную активацию отдельных участков миокарда.

Значительно реже диагностируется ГКМП у представителей видов спорта на развитие выносливости, в тренировочном процессе которых преобладают объемные аэробные нагрузки, способствующие фрормированию дилатации полости левого желудочка сердца [19].

Гипертрофическая кардиомиопатия вызывается наличием аутосомно-доминантных генетических нарушений, ведущих к нарушению кодирования белков в саркомерах сердца, приводящих к асимметричной гипертрофии левого (чаще) или правого желудочка с неправильным хаотическим расположением мышечных волокон. При этом в отсутствии нарушений структуры и деятельности аортального клапана, артериальной гипертонии отмечается асимметричная гипертрофия межжелудочковой перегородки и стенок левого желудочка с нарушением диастолической функции и уменьшением объема его полости, а также нарушение деятельности митрального клапана.

У спортсменов с ГКМП определяется асимметричная гипертрофия левого желудочка в $70 \%$ случаев, а симметричная - у 30 \% обследованных. Часто фриксируется асимметрическая гипертрофия межжелудочковой перегородки, которая занимает перегородку полностью или ее базальную часть. Реже встречается гипертрофия верхушечной области, заднеперегородочной или боковой стенки левого желудочка. В зависимости от наличия градиента систолического давления выходного тракта различают гипертрофию левого желудочка с обструкцией или без обструкции выходного тракта [18, 19].

Развитие ГКМП ведет к изменению систолической и нарушению диастолической функции левого желудочка, фрормированию динамического градиента давления в его полости и ишемии миокарда. Считается, что аритмогенным субстратом являются очаги дезорганизации кардиомиоцитов и фриброза, которые по мере прогрессирующего развития фриброза сердечной мышцы становятся источниками формирования желудочковых тахиаритмий, обусловливающих развитие внезапной смерти [20]. При фризической нагрузке повыша- 


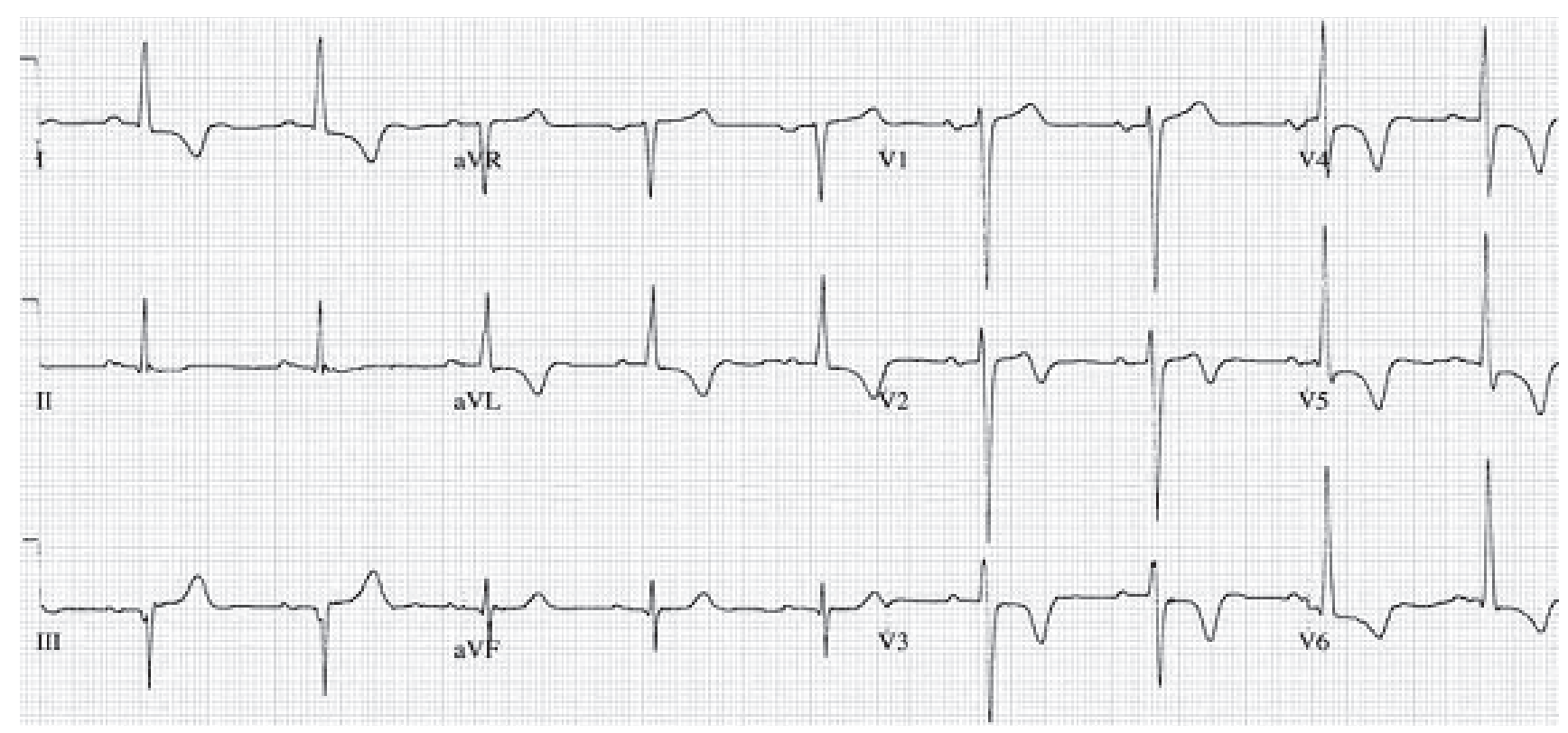

Рисунок 2 - Нарушения процесса реполяризации при гипертрофической кардиомиопатии

ется симпатостимуляция миокарда, происходит дегидратация организма, нарушается минеральный баланс, развивается ишемия миокарда, запускающие аритмогенный триггерный механизм, ведущий к формированию несовместимых с жизнью желудочковых тахикардий и фрибрилляции желудочков [21, 22].

Несмотря на то что изменения ЭКГ не являются частью диагностического алгоритма ГКМП, весьма часто постановка диагноза начинается именно с обнаружения изменений на ЭКГ. У $90 \%$ пациентов с асимптоматичной ГКМП был выявлен хотя бы один ЭКГ-признак [23], которыми являлись инверсия зубца Т в $62 \%$ случаев (рис. 2), неамплитудные признаки гипертрофии левого желудочка у 60 \% обследованных и появление зубца $Q$ в грудных отведениях в $48 \%$ случаев (рис. 3 ).

Зубец Q при гипертрофрической кардиомиопатии фрормируется из-за развивающейся асимметричной гипертрофии миокарда левого желудочка и изменения направления начального вектора возбуждения к отрицательному полюсу регистрирующего отведения. Зубец $Q$ чаще определяется в нижних (II, III, aVF и $\mathrm{V}_{6}$ ) отведениях. Критериями патологичности зубца $Q$ у молодых спортсменов [23] является его увеличение по амплитуде более 3 мм и по времени более 0,04 с в стандартных и грудных отведениях, за исключением отведений $\mathrm{aVR}$, III и V .

Среднюю частоту выявления у обследованных спортсменов составили депрессия сегмента ST в нижне-латеральных отведениях (27 \%) и увеличение левого предсердия (21\%). Более низкую частоту проявления имели такие признаки, как поворот электрической оси сердца влево (в $19 \%$ случаев) и замедление внутрижелудочковой проводимости (у 13\% обследованных). Единичный признак изменений ЭКГ при постановке диагноза ГКМП является частично значимым, более информативным является определение наличия нескольких ЭКГ-признаков. А решающими методиками в постановке диагноза ГКМП являются ЭхоКГ (54 \%) и МРТ (89\%), дополненные результатами холтеровского мониторинга и пробы с фризической нагрузкой [24, 25].

Кардиопульмональная проба позволяет определить величину максимального потребления кислорода в абсолютных и относительных (на 1 кг массы тела) значениях, а также рассчитать процент от теоретического максимума для спортсмена конкретного вида спорта. Холтеровский мониторинг проводится для выявления бессимптомных аритмий, дисфункции синусового узла и нарушения проведения по пучку Гиса.

Если у спортсмена толщина стенки левого желудочка сердца находится в диапазоне от 13 до 15 мм, а у спортсменки - от 11 до 13 мм, а конечно-диастолический диаметр левого желудочка у них определен в промежутке от 45 до 60 мм, то они находятся в потенциально опасной «серой зоне». У таких спортсменов необходимо выяснить, являются ли изменения миокарда результатом многолетних занятий спортом или вызваны развивающейся ГКМП с помощью дополнительных методов обследования. По результатам обследования выносится решение о возможности продолжения спортивной деятельности. 


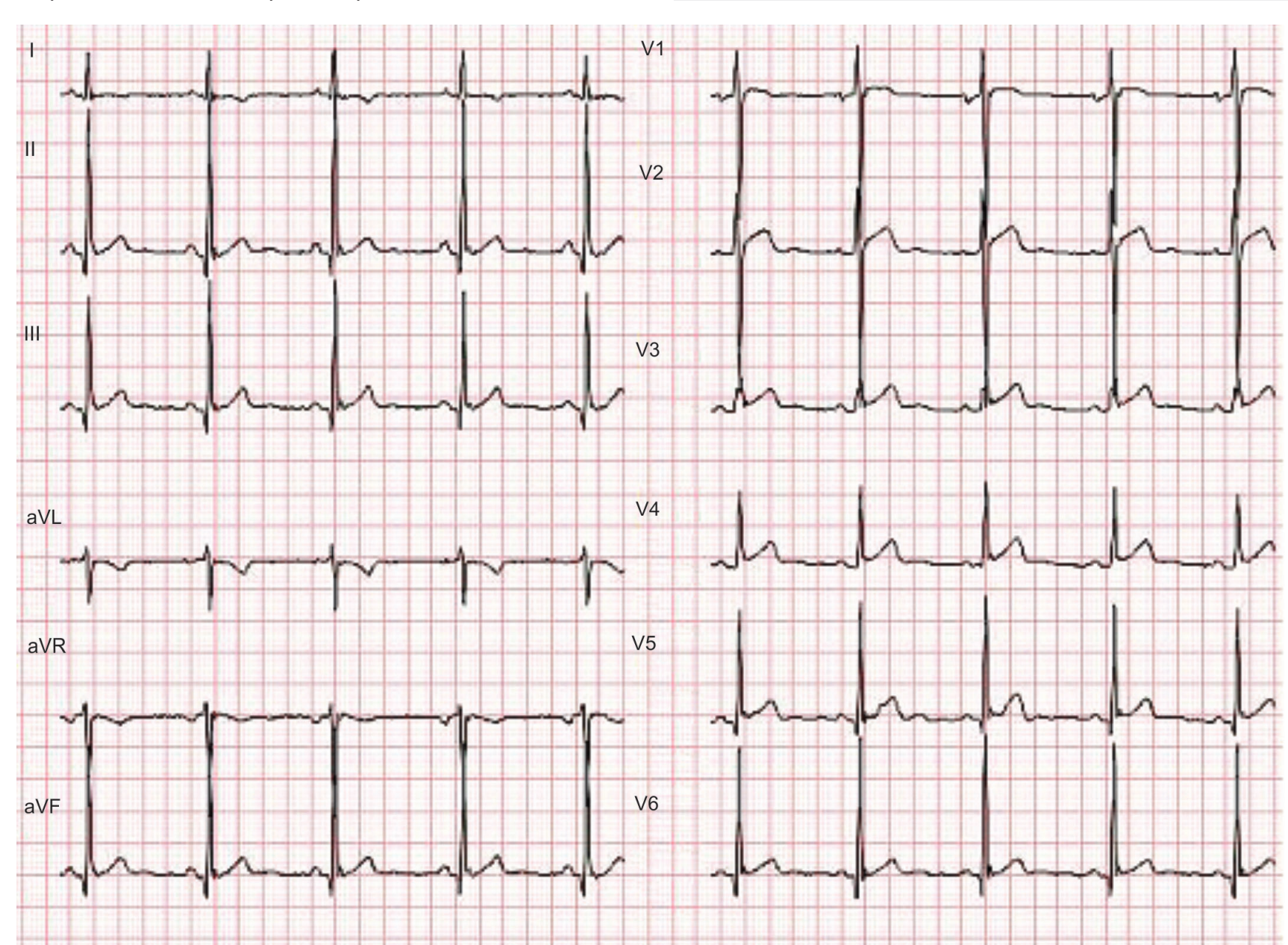

Рисунок 3 - Патологический зубец Q при гипертрофической кардиомиопатии

Для дифрференциальной диагностики «сердца спортсмена» и ГКМП используются критерии [26], представленные в таблице 1.

Разработаны руководства по диагностике и ведению спортсмена с подозрением на КГМП [26]. Начинается диагностика с выявления ЭКГ изменений, позволяющих поставить вопрос о наличии КГМП у спортсменов при ежегодном обследовании. Дополнительные обследования включают сбор личного и семейного анамнеза, физикальное обследование. При проведении ЭхоКГ в дополнение к измерению толщины мышечных стенок и размера камер сердца, изучению функции клапанов сердца, выявлению гипертрофии сегментов левого (реже правого) желудочка без дилатации их полости, обязательно проводится определение систолической и диастолической функции желудочков сердца.

Наблюдения за спортсменами должны быть регулярными (один раз в год) и многолетними, так как лонгитудинальное исследование 81 спортсмена [27], имеющего на ЭКГ глубокий инвертированный зубец Т в трех и более отведе- ниях, выявило у пяти из них развитие ГКМП за период в $9 \pm 7$ лет. Однако имеются данные и о более быстром развитии ГКМП у спортсменов с такими же изменениями зубца Т, в среднем за 12 мес. (24).

Имеются данные, что процесс ремоделирования миокарда при ГКМП сопровождается гипертрофией кардиомиоцитов, деструкцией саркомера и развитием фриброза. Развитие фииброза сопровождается накоплением высокочувствительного сердечного тропонина (hs-cTnT) и натрийуретического пептида Б типа (BNP), которые могут рассматриваться как биомаркеры фииброза при ГКМП (28). Имеются также работы, указывающие на фрункциональную роль сигнальных наномолекул, микрорибонуклеиновых кислот (miRNA) в развитии гипертрофии и фиброза миокарда при ГКМП [29]. В настоящее время усилия ученых направлены на полную валидацию клинической значимости этих биомаркеров.

При подтвержденном диагнозе ГКМП спортсмены не допускаются к занятиям спортом. В сомнительных случаях при неподтвержденном 
ТАБЛИЦА 1 - Дифференциальная диагностика «сердца спортсмена» и гипертрофической кардиомиопатии (Еlliott et al., 2014)

\begin{tabular}{|c|c|c|}
\hline Признак & «Сердце спортсмена» & Гипертрофическая кардиомиопатия \\
\hline Патологический зубец Q & Отсутствует & Имеется \\
\hline Инверсия зубца Т, депрессия сегмента ST & Отсутствуют & Имеются \\
\hline Толщина стенки левого желудочка сердца & $\begin{array}{l}\text { Мужчины < } 13 \text { мм } \\
\text { Женщины < } 11 \text { мм }\end{array}$ & $\begin{array}{l}\text { Мужчины > } 15 \text { мм } \\
\text { Женщины > } 13 \text { мм }\end{array}$ \\
\hline $\begin{array}{l}\text { Конечно-диастолический диаметр левого } \\
\text { желудочка }\end{array}$ & $>60 \mathrm{~mm}$ & $<45$ мM \\
\hline Диастолическая функция левого желудочка & $\begin{array}{l}\text { Нормальная } \\
(\text { соотношение A:E > 1)* }\end{array}$ & $\begin{array}{l}\text { Нарушена } \\
(\text { соотношение A:E }<1)^{*}\end{array}$ \\
\hline Гипертрофия межжелудочковой перегородки & Симметричная & Асимметричная \\
\hline Максимальное потребление кислорода & $\begin{array}{l}>50 \text { мл'мин }{ }^{-1} \cdot \text { кг или }>80 \% \text { от теоретиче- } \\
\text { ского максимума }\end{array}$ & $\begin{array}{l}<50 \text { мл·мин }{ }^{-1} \cdot \text { кг или }<80 \text { \% теоретиче- } \\
\text { ского максимума }\end{array}$ \\
\hline Семейный анамнез & Нормальный & Осложненный \\
\hline $\begin{array}{l}\text { Реакция систолического давления на } \\
\text { физическую нагрузку }\end{array}$ & Нормальная & $\begin{array}{l}\text { Нормальная или с недостаточным } \\
\text { повышением СД }\end{array}$ \\
\hline Прекращение тренировочного процесса & $\begin{array}{l}\text { Обратное развитие гипертрофии левого } \\
\text { желудочка }\end{array}$ & $\begin{array}{l}\text { Обратное развитие гипертрофии не } \\
\text { происходит }\end{array}$ \\
\hline
\end{tabular}

* A:E - соотношение начальной и конечной скорости трансмитрального потока.

диагнозе, если случаи внезапной сердечной смерти или ГКМП в семейном анамнезе исключены, отсутствуют клинические симптомы, аритмии или значительная гипертрофрия, то при нормальной диастолической функции и адекватной реакции артериального давления на фризическую нагрузку такие лица допускаются к занятиям малонагрузочными видами спорта. При этом они нуждаются в динамическом клиническом и инструментальном обследовании с частотой один раз в год.

При выявлении у спортсмена синкопе, наличия случаев внезапной сердечной смерти в семейном анамнезе, значительной гипертрофии левого желудочка, постоянной или преходящей желудочковой тахикардии, снижения реакции артериального давления на фризическую нагрузку ставится вопрос о необходимости имплантации кардиовертер-дефибриллятора [25].

\section{Аномалии коронарных артерий}

Следующей причиной по частоте внезапной сердечной смерти (17 \% случаев) у молодых спортсменов являются аномалии коронарных артерий [30, 31]. Формирование аномалии обусловлено отхождением левой коронарной артерии от правого синуса (Вальсальвы) с резким поворотом, образующим острый угол с аортой, располагающейся между стволом пульмональных артерий и передней частью аорты. При таком расположении левая коронарная артерия может подвергаться сдавливанию аортой или пульмональными артериями. Сдавливание артерии вызывает дисфункцию эндотелия, а недо- статочный кровоток, особенно при фризической нагрузке, ведет к развитию ишемии миокарда, способной вызвать жизнеопасные нарушения ритма сердца. Более редко аномалия проявляется отхождением правой коронарной артерии от левого синуса или врожденной гипоплазией коронарных артерий [32]. Распространенность аномалии коронарных артерий у разных контингентов обследованных колеблется от 0,32 до 5,79\% [33]. Частота изолированных аномалий коронарных артерий составляет 0,6-1,8 \% объема всех проводимых коронарографий [34].

Патология редко диагностируется при жизни спортсменов, диагноз обычно ставится после вскрытия внезапно умершего спортсмена. У таких спортсменов на ранних этапах развития болезни отсутствует как клиническая симптоматика, так и патологические признаки на ЭКГ в состоянии покоя и при фризической нагрузке. Подозрение на наличие такой патологии возникает при появлении у спортсмена клинических признаков: синкопе во время выполнения фризической нагрузки, появление желудочковых тахиаритмий. В дальнейшем могут появляться боли за грудиной, чувство неадекватной усталости во время или после фризической нагрузки, учащение эпизодов синкопе, вентрикулярных тахиаритмий и ишемии миокарда во время выполнения фризической нагрузки.

При подозрении на наличие аномалии коронарных артерий в комплекс обследования входят сбор личного и семейного анамнеза, регистрация ЭКГ в покое и при оризической нагрузке, проведение ЭхоКГ и МРТ сердца. В сомнительных 
случаях необходимо использовать для уточнения диагноза коронароангиографию или мультиспиральную компьютерную томографию (МСКТ).

При выявлении аномалии коронарных сосудов спортсмен должен быть отстранен от занятий всеми видами спорта. После оперативного лечения спортсмен при отсутствии ишемии миокарда, желудочковых тахиаритмий и нарушений функции желудочков сердца при выполнении пробы с максимальной фризической нагрузкой допускается к занятиям любым видом спорта.

\section{Миокардит}

Как причина внезапной сердечной смерти у спортсменов миокардит выявляется в 5 \% случаев [5]. Миокардит представляет собой поражение сердечной мышцы воспалительным процессом, обусловленное непосредственным или опосредованным, через иммунные механизмы, воздействием вирусной или бактериальной инфекции, химических или фризических фракторов, а также влияниями, возникающими при аллергических и аутоиммунных заболеваниях. Из бактериальных факторов преобладают возбудители рода Chlamydia. А среди других причин выделяют прямое и опосредованное воздействие токсических веществ, в том числе лекарственных средств, допинга, а также аллергические и аутоиммунные реакции.

Процесс воспаления миокарда сопровождается развитием воспалительной инфильтрации, интерстициальным отеком, формированием очагов некроза кардиомиоцитов, с последующим развитием фриброзных изменений, ведущих к развитию электрической нестабильности миокарда как причины развития желудочковых тахиаритмий $[5,35]$.

У спортсмена выясняется наличие перенесенной вирусной или бактериальной инфекции и последующих за этим нарушений самочувствия: усталость, сонливость, потеря аппетита, боли за грудиной, субфебрильная температура, одышка при выполнении фризической нагрузки, высокая частота сердцебиений в покое, пре- и обморочные состояния, желудочковые тахиаритмии, низкая переносимость физической нагрузки. В постановке диагноза существенную роль играют лабораторные (маркеры воспаления) исследования, динамические изменения ЭКГ-признаков и изучение систолической и диастолической фрункции сердца с помощью эхокардиографии.

Изменения на ЭКГ при миокардите носят неспецифический характер, могут проявляться в виде нарушений проводимости (AВ-блокада I или II степени, внутрижелудочковые блокады и т.д.), возбудимости (синусовая тахикардия, экстрасистолия, эктопические ритмы, тахиаритмии и т.д.), дифрфузного нарушения реполяризации миокарда (незначительная депрессия сегмента ST и сглаженный, отрицательный зубец Т во многих отведениях), снижения амплитуды комплексов QRS, удлинения электрической систолы сердца (рис. 4). Степень выраженности изменений на ЭКГ определяется тяжестью поражения и выраженностью развития фиброзных изменений миокарда.

Ранняя постановка диагноза и правильное лечение значительно снижают тяжесть течения заболевания, устраняют возможность усугубляющего влияния фризических нагрузок на миокард во время болезни, снижают частоту осложнений, ускоряют процесс выздоровления [35].

После перенесенного спортсменом миокардита занятия всеми видами спорта запрещены в течение 6 мес. с момента появления клинических признаков. По прошествии этого срока спортсменам с нормальной морфологией и фрункцией сердца, при отсутствии желудочковой аритмии в покое и при фризической нагрузке, при нормализации маркеров воспаления и восстановлении нормальной картины ЭКГ покоя и при физической нагрузке допускаются к занятиям всеми видами спорта без ограничений [11, 36, 37]

При наличии вышеуказанных признаков после 6-месячного перерыва в занятиях спортом в зависимости от состояния спортсмена пауза в занятиях спортом может продлеваться еще на 6 мес. Повторное клиническое обследование проводится в полном объеме (ЭКГ покоя, ЭхоКГ, 24-часовой холтеровский мониторинг, проба с фризической нагрузкой) для решения о допуске спортсмена к занятиям спортом без ограничений, с определенными ограничениями или полным прекращением активного тренировочного и соревновательного процесса.

\section{Аритмогенная дисплазия правого желудочка сердца}

Аритмогенная дисплазия правого желудочка (АДПЖ) сердца как причина внезапной сердечной смерти у спортсменов выявлена в 4 \% случаев [5]. Имеются данные об эндемическом характере этого заболевания, которое в Италии в регионе Венето является наиболее частой (13\%) причиной внезапной смерти у лиц в возрасте до 35 лет, причем преобладают случаи смерти у молодых спортсменов [37]. У английских спортсменов причиной внезапной сердечной смерти АДПЖ стала в $13 \%$ случаев [38]. 


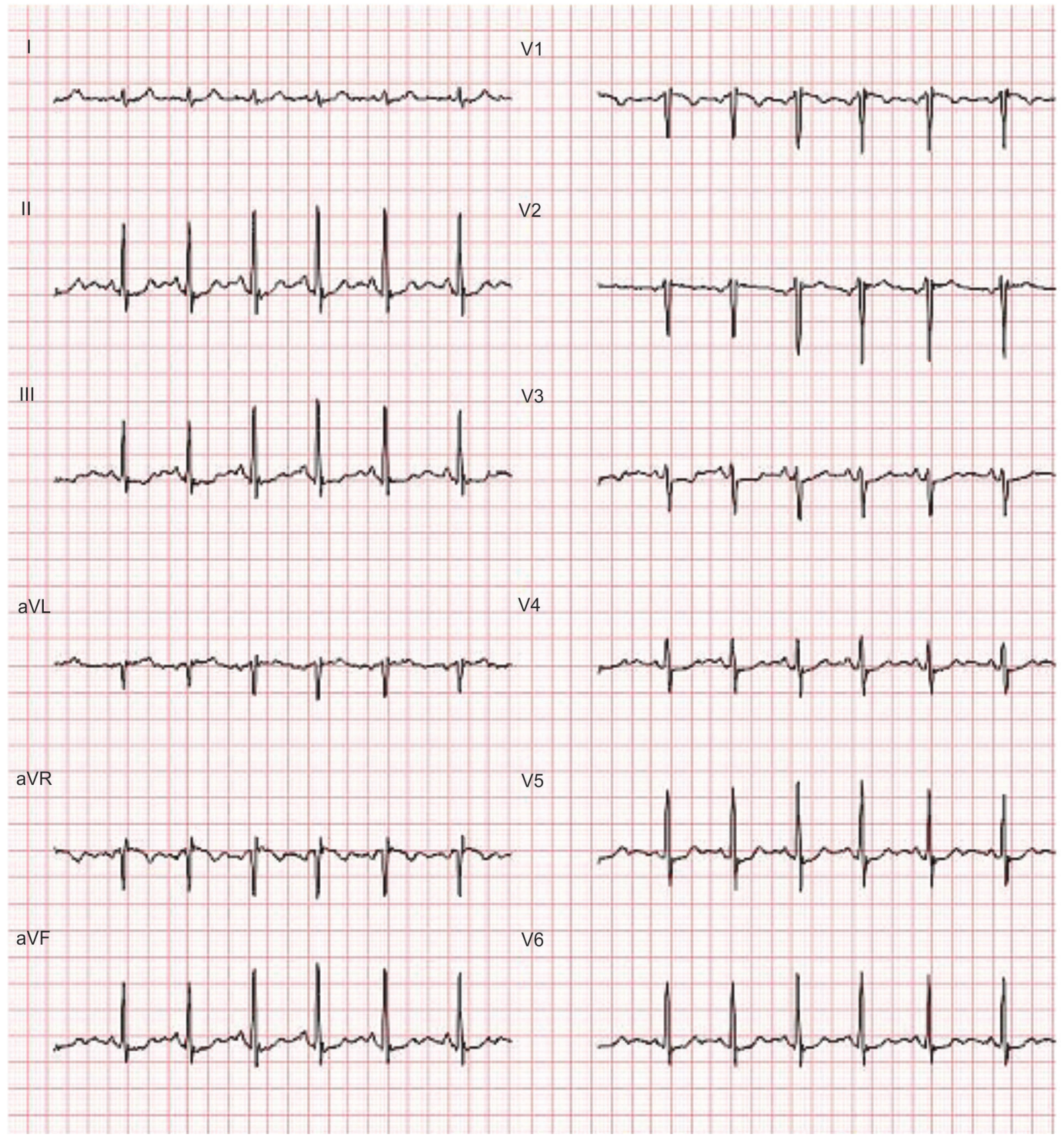

Рисунок 4 - Нарушения процесса реполяризации миокарда у спортсменки с диагнозом миокардит в активной фразе

Считается, что АДПЖ является врожденным заболеванием миокарда аутосомно-доминантного типа, вызванным мутацией генов, кодирующих десмосомные белки, что приводит к формированию в миокарде проникающих очагов поражения с разной степенью выраженности [39, 40, 41]. Генетическая природа заболевания пока полностью не доказана, хотя уже картированы семь участков четырех $[1,3,10,14]$ хромосом [42). Эти участки гена, обусловливающие заболевание, ассоциируются с десмосомными белками, включая плакоглобин, десмоплакин, плакофилин и десмоглеин [43].

Возникает АДПЖ в результате сегментарного фриброзно-жирового перерождения мышечных волокон правого желудочка сердца, локализирующихся в «треугольнике дисплазии» (выходной тракт, верхушка и входной тракт), ведущие к развитию электрической нестабильности миокарда и появлению желудочковых тахиаритмий $[44,45]$.

Развитие процесса начинается с эпикарда, затем происходит его распространение на эндо- 
кард и в конечном итоге фрормируется трансмуральное поражение миокарда правого желудочка. Ослабление стенки миокарда способствует формированию дилатации и аневризмы на нижней и апикальной стенке правого желудочка сердца.

Развитие дисплазии в правом желудочке обусловлено метаболическими нарушениями, которые способствуют прогрессирующему замещению кардиомиоцитов фриброзно-жировой тканью, являющейся источником желудочковых аритмий. В области замещения происходит замедление внутрижелудочковой проводимости, отражающееся формированием позднего потенциала, эпсилон волны и блокады правой ножки пучка Гиса. При этом проявляется дисперсия рефрактерности из-за наличия отдельных участков жизнеспособного миокарда в фиирозно-жировой ткани, замедление внутрижелудочковой проводимости и наличие электрической деполяризации в диастолу, способствующие возникновению экстрасистол, способных, в случае развития кругового движения импульса, вызывать желудочковую тахиаритмию, переходящую в фибрилляцию сердца и его остановку [11, 46]. Возникновение желудочковых тахиаритмий провоцируется адренэргическими воздействиями, в частности, фризической нагрузкой, эмоциональным стрессом [42, 44].

Для АДПЖ характерно наличие желудочковых экстрасистол (более 500 за 24 ч) из области выходного тракта правого желудочка, которые имеют конфигурацию блокады левой ножки пучка Гиса (комплекс QRS в отведении V 1 направлен вниз), а в стандартных отведениях выявляется изменение направления электрической оси сердца, на ЭКГ фриксируется наличие постоянных или непостоянных желудочковых аритмий [41]. Прогрессирующая дилатация и развивающаяся дисфункция правого желудочка сердца ведут к снижению его насосной функции, а затем на фоне этих изменений происходит вовлечение в процесс и левого желудочка сердца. Наряду с уширением и расщеплением комплекса QRS более 0,12 с чувствительными маркерами заболевания являются нарушения реполяризации миокарда: отрицательные зубцы Т в правых грудных отведениях $\mathrm{V}_{2}$ и $\mathrm{V}_{3}$, а также расширение восходящей части зубца $S$ и появление волны эпсилон в правых грудных отведениях [48].

Длительность комплекса QRS в правых грудных отведениях превышает продолжительность комплекса QRS в левых грудных отведениях: соотношение длительности комплекса QRS в $\mathrm{V}_{2} \kappa$ длительности QRS в $\mathrm{V}_{4}$, а также суммы продол-

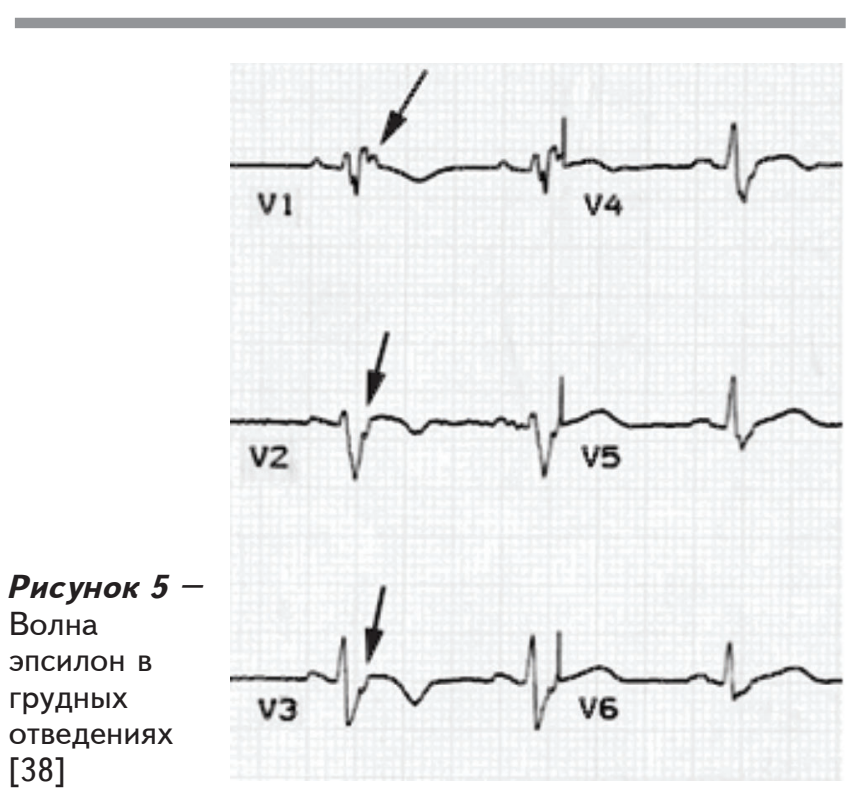

жительности комплекса QRS в отведениях $\mathrm{V}_{1}$ и $\mathrm{V}_{3}$ к их сумме в отведениях $\mathrm{V}_{4}$ и $\mathrm{V}_{6}$ превышает единицу [45].

Волна эпсилон (рис. 5) отражает замедленную волну деполяризации правого желудочка и представляет собой низкоамплитудный сигнал между окончанием комплекса QRS и началом сегмента ST [11, 47]. Для АДПЖ характерно расположение Ј-точки на изолинии, что исключает нарушение начального процесса реполяризации миокарда, в то время как при синдроме ранней реполяризации миокарда Ј-точка приподнята над изолинией [48].

Отмечается снижение амплитуды зубца R в стандартных отведениях и появление сначала отдельных, а затем частых желудочковых экстрасистол, ведущих к развитию пароксизма желудочковой тахикардии. Поскольку очаг возбуждения находится в правом желудочке, то эктопические желудочковые комплексы имеют вид блокады левой ножки пучка Гиса. Помимо обычной ЭКГ для проведения диагностики показан 24- или 48-часовой холтеровский мониторинг для выявления наличия и числа желудочковых экстрасистол, эпизодов желудочковой тахиаритмии. Показано использование сигнал-усредненной ЭКГ, которая при наличии АДПЖ становится анормальной [45].

Однако более важными методами диагностики аритмогенной дисплазии правого желудочка сердца являются эхокардиография и магнитно-резонансная томография. ЭхоКГ позволяет выявить конечно-систолические и конечно-диастолические размеры и объемы желудочков сердца, несбалансированную дилатацию и аномальное движение стенки правого желудочка, а МРТ дает возможность выявить повышенное содержание жировой 
ТАБЛИЦА 2 - Дифференциальная диагностика «сердца спортсмена» и аритмогенной дисплазии правого желудочка [25]

\begin{tabular}{|c|c|c|}
\hline Признак & «Сердце спортсмена» & $\begin{array}{c}\text { Аритмогенная дисплазия правого } \\
\text { желудочка }\end{array}$ \\
\hline Патологический зубец Q & Отсутствует & Имеется \\
\hline Инверсия зубца Т в отведениях $\mathrm{V}_{2}, \mathrm{~V}_{3}$ & Отсутствует & Имеется \\
\hline Волна эпсилон & Отсутствует & Имеется \\
\hline Соотношение объема правого к объему левого желудочка сердца & $<1,2$ & $>1,2$ \\
\hline Движения стенки правого желудочка & Нормальные & Анормальные \\
\hline Фиброз правого желудочка & Отсутствует & Имеется \\
\hline Блокада правой ножки пучка Гиса & Частичная (QRS <0,12 сек) & Полная (QRS 0,12 сек и более) \\
\hline Желудочковые экстрасистолы, имеющие вид БЛНПГ & Отсутствуют & Имеются(более 1000 за 24 ч) \\
\hline Дилатация правого желудочка (общая или сегментарная) & Отсутствует & Имеется \\
\hline Функция правого и левого желудочков & Нормальная & Нарушена \\
\hline Семейный анамнез & Нормальный & Осложненный \\
\hline
\end{tabular}

ткани, а также замещение кардиомиоцитов фиброзно-жировой тканью в миокарде правого желудочка. На поздних стадиях развития болезни происходит поражение также левого желудочка сердца, ведущее к развитию его диссрункция.

Для диффреренциальной диагностики «сердца спортсмена» и АДПЖ у спортсменов (табл. 2) используются морфологические и функциональные показатели правого желудочка, ЭКГ-признаки и данные семейного анамнеза $[11,25]$.

У спортсменов элитного уровня в видах спорта на развитие выносливости АДПЖ может развиваться без десмосомных нарушений миокарда. Возможно причиной возникновения болезни является чрезмерная нагрузка большим возвратным объемом крови на правый желудочек сердца, усиленная адренергическая стимуляция миокарда и повышенная механическая нагрузка на миокард, формирующие так называемую индуцированную физической нагрузкой АДПЖ [17].

Поскольку первым клиническим признаком наличия болезни может стать внезапная смерть, необходимо принимать меры по выявлению лиц, имеющих семейную предрасположенность к заболеванию (внезапная сердечная смерть в возрасте до 35 лет). Для таких спортсменов показано проведение углубленного личного и семейного анамнеза, электро- и эхокардиографии, 48-часовой холтеровский мониторинг и МРТ. В случае выявления у спортсмена изолированных участков миокарда, вызывающих желудочковую тахиаритмию, показана их радиочастотная аблация.

Из-за высокого риска внезапной смерти в результате злокачественной желудочковой тахиаритмии, переходящей в фрибрилляцию желудочков, занятия спортом лицам с аритмогенной дисплазией правого желудочка сердца абсолютно противопоказаны. Однако отмечено улучшение
ЭКГ-картины (нормализация зубца Т в правых грудных отведениях) у лиц с АДПЖ [50] под влиянием оптимальной фризической нагрузки. В то же время в зависимости от состояния спортсмена для профилактики развития или прогрессирования АДПЖ рекомендуется здоровый образ жизни, проводится медикаментозная терапия или радиочастотная аблация аритмогенных участков миокарда, имплантируется кардиовертер-десибриллятор.

\section{Дилатационная кардиомиопатия}

Дилатационная кардиомиопатия (ДКМП) изредка является причиной смерти у спортсменов, поскольку у лиц с такой патологией уже в раннем возрасте имеются нарушения сердечной деятельности с проявлением клинических симптомов, что ограничивает их спортивные достижения и спортивная карьера у них заканчивается рано.

Причиной заболевания являются аутосомнодоминантные мутации гена саркомерного протеина, Z-цепей и клеточной мембраны, вызывающие метаболические нарушения миокарда, ведущие к развитию электрической нестабильности миокарда и способствующие возникновению злокачественных нарушений ритма, которые могут привести к внезапной сердечной смерти [51].

Для ДКМП характерны изменения сердечной мышцы, сопровождающиеся значительным увеличением полости и эксцентрической гипертрофрией левого желудочка сердца, приводящих к нарушению его систолической и диастолической функции, резкому снижению сократимости миокарда и уменьшению фрракции изгнания левого желудочка сердца. На фоне нарушений функции левого желудочка основной опасностью является возможное развитие желудочковых тахиа- 


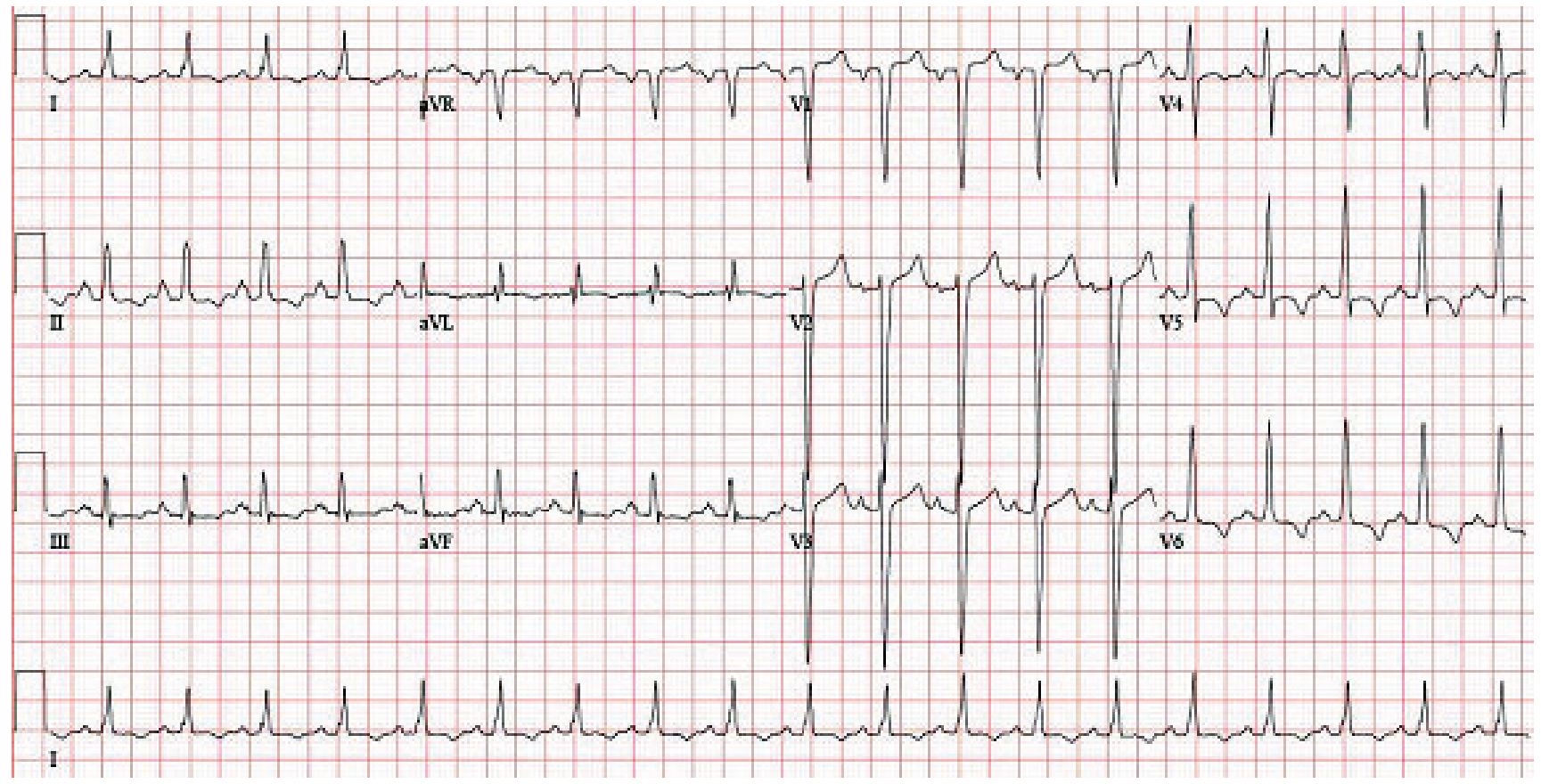

Рисунок 6 - Гипертрофии левого желудочка при дилатационной кардиомиопатии

ритмий, ведущих к фибрилляции желудочков и летальному исходу.

Главными диагностическими методами в постановке диагноза ДКМП являются эхокардиограсрия и магнитно-резонансная томографияя. Однако и на ЭКГ фрормируются характерные для данной патологии признаки.

1. Признаки гипертрофрии левого желудочка в грудных отведениях.

2. Уменьшение амплитуды зубца R в стандартных отведениях.

3. Неадекватный (замедленный) прогресс увеличения зубца R в грудных отведениях от $\mathrm{V}_{1}$ к V $\mathrm{V}_{6}$ [52].

4. Блокада левой ножки пучка Гиса [53].

В процессе развития дилатационной кардиомиопатии по данным ЭхоКГ и МРТ увеличивается конечно-диастолический объем левого желудочка сердца более 120 мл (отношение величины к площади тела $>65$ мл/ м $^{2}$ ). Конечно-диастолический диаметр левого желудочка увеличивается на начальном этапе более 60 мм (отношение к площади тела >32 мл м $^{2}$ ), а в дальнейшем более 65 мм (>33 мл м $\left.^{2}\right)$. При развитии болезни рассчитанная по этим методикам величина фрракции изгнания уменьшается ниже нормальных значений (менее 50 \%), а в подтвержденных случаях становится менее $45 \%$ [24]. По результатам кардиопульмональной пробы с физической нагрузкой отмечается снижение уровня потребления кислорода менее 85 \% теоретического возрастного максимума, причем редко определяются значения более 40 мл $\cdot \mathrm{мин}^{-1} \cdot \mathrm{Kг}^{-1}$ [54].
Спортсменам с таким диагнозом занятия соревновательным спортом запрещены.

Лицам с низким уровнем риска, у которых не выявлены случаи внезапной смерти в семейном анамнезе, отсутствуют клинические симптомы, отмечается легкое снижение систолической фрункции левого желудочка сердца (фрракция изгнания не ниже $40 \%$ ), при нормальной реакции артериального давления на фризическую нагрузку и отсутствии желудочковых аритмий на ЭКГ при 24- или 48-часовом холтеровском мониторинге допускаются к занятиям оздоровительной физической культурой [55].

При снижении у обследуемого величины фрракции изгнания желудочков менее $35 \%$ и удлинении длительности комплекса QRS более 0,12 с показана имплантация кардиовертер-дефрибриллятора.

\section{Атеросклероз коронарных артерий}

У спортсменов в возрасте старше 35 лет атеросклероз коронарных артерий является наиболее частой причиной внезапной сердечной смерти в процессе выполнения тренировочной или соревновательной нагрузки [5, 7, 25, 56]. Уменьшение просвета крупных коронарных артерий более чем на $75 \%$, чаще передней левой нисходящей коронарной артерии, ведет к внезапной сердечной смерти в результате развития инфаркта миокарда и вызванными осложнениями в виде нарушений ритма и проводимости, ведущих к остановке сердца. Причиной значительного су- 
жения артерий могут также стать атеромы передней левой нисходящей и правой коронарной артерий, вызывающие эрозию стенки артерий и создающие условия для развития их тромбоза и закупорки сосуда.

Имеются данные о спазме коронарных артерий как о фракторе, вызывающем ВСС, в результате нарушения микроциркуляции в эпикардиальных коронарных сегментах, ведущих к снижению резерва коронарной перфузии и ишемии миокарда [57, 58].

Атеросклеротические изменения коронарных сосудов в условиях мышечного покоя клинически могут не проявляться, а на ЭКГ могут регистрироваться неспецифические признаки нарушения реполяризации миокарда в виде незначительных изменений сегмента ST и зубца T.

Однако во время выполнения фризической нагрузки из-за наличия атеросклеротических изменений или возникающего спазма коронарных сосудов коронарный кровоток не способен обеспечить возрастающие потребности миокарда в кислороде. Выполнение фризической нагрузки вызывает также транзиторное повышение свертываемости крови, что при наличии коронарного атеросклероза значительно повышает риск осложнений. Несоответствие между поступающим количеством кислорода и запросом миокарда в кислороде ведет к повышению риска развития острых коронарных осложнений и жизнеугрожающей ишемии миокарда.

Причиной аритмогенной остановки сердца могут стать желудочковая пароксизмальная тахикардия и фрибрилляция желудочков, вызываемые из очага некроза при развитии острого инфраркта миокарда, а также электрическая нестабильность миокарда, обусловленная влиянием на миокард повышенной симпатостимуляции при выполнении физической нагрузки.

Поэтому спортсмены, ощущающие дискомфорт, давящие, душащие, сжимающие боли в области сердца, иррадиирующие в левую руку, плечо, шею, сопровождающиеся одышкой, тошнотой, рвотой, обильным потоотделением, развитием предобморочного состояния или обморока, сопровождающиеся развивающейся горизонтальной или косонисходящей депрессией сегмента ST более 1 мм при выполнении пробы с фризической нагрузкой, а также имеющие частую полиморфную тахиаритмию в покое и при выполнении нагрузочной пробы, уменьшенную фрракцию изгнания менее $50 \%$, стеноз главных коронарных артерий более 50 \% (по данным ангиографии), не допускаются к занятиям спортом.
Спортсмены с диагнозом ИБС, не имеющие вышеописанных признаков, допускаются к занятиям малонагрузочными видами спорта и оздоровительной физической культурой.

Профилактика ИБС у спортсменов заключается в нормализации массы тела, снижении увеличенного процента жировой ткани в организме, устранении дислипидемии (нормализация уровня общего холестерина, триглицеридов и холестерина низкой плотности), снижении повышенного артериального давления, организации сбалансированного тренировочного процесса с оптимальным процентом аэробной нагрузки низкой и средней интенсивности, уменьшении стрессовых воздействий в быту, на тренировках и соревнованиях [1, 3, 59].

Серьезным фактором риска развития ИБС является внезапное прекращение занятий спортом спортсменами в возрасте старше 30 лет, которое происходит из-за снижения спортивных результатов, под влиянием хронических заболеваний и травм, по финансовым соображениям, по семейным обстоятельствам и т.д. Резкое снижение физической нагрузки вызывает нарушения регуляции обменных процессов, что ведет к появлению излишней массы тела, формированию дислипидемии, повышению артериального давления, а если добавляются вредные привычки (курение, прием алкоголя), то создаются условия развития атеросклероза, в том числе и коронарных артерий, ведущего к развитию ИБС [60].

Спортсмены должны заканчивать свою спортивную карьеру постепенно, снижая количество соревнований, уменьшая тренировочную нагрузку, но при этом обязаны сохранить в достаточном объеме аэробные нагрузки низкой и средней интенсивности для сохранения в организме обменных процессов на должном уровне, для обеспечения оптимальной нагрузки на сердце и обеспечения кардиопротекторного эффекта.

\section{Сотрясение сердца}

У спортсменов клиническое проявление сотрясения сердца развивается во время тренировочной и соревновательной деятельности после фризического воздействия соперника или летящего снаряда [61, 62]. Сотрясению сердца более подвержены лица европеоидной расы мужского пола в возрасте 13-18 лет. В большинстве случаев после фризического воздействия спортсмен теряет сознание, некоторые из них перед этим чувствуют головную боль. В начале процесса оживления у пострадавшего фриксируется фрибрилляция желудочков, которая при отсутствии результатов эфрфективного оживления может перейти в асистолию сердца. 
Внезапная сердечная смерть возникает у спортсмена без заболевания сердца и при отсутствии структурных изменений миокарда в результате резкого короткого непроникающего удара по грудной клетке в уязвимую фразу реполяризации желудочков, представляющую собой временной период от 10 до 20 мс на подъеме зубца Т, непосредственно перед его пиком, который составляет только 0,5-1,5 \% времени сердечного цикла. При попадании удара в уязвимую фазу механическая энергия удара вызывает активацию ионных каналов миокарда, ведущую к появлению усиленной циркуляции волны реполяризации, фрормированию неоднородной активации и электрической нестабильности миокарда.

В этих условиях желудочковая экстрасистола может стать пусковым механизмом развития фрибрилляции желудочков с высокой вероятностью летального исхода. Быстрой передаче энергии удара на сердце способствует тонкая, эластичная грудная стенка у юных и молодых спортсменов. При этом у пострадавшего отсутствует повреждение сердца, способное само по себе вызвать летальный исход [61-63].

Ситуация чаще встречается в контактных (бокс, все виды борьбы, восточные единоборства и т.д.) и игровых (хоккей на льду, регби, футбол, баскетбол и т.д.) видах спорта при фризическом воздействии соперника или быстро летящих снарядов (шайбы, мяча и т.д.) на грудную клетку. Поскольку временной интервал уязвимой фазы весьма короткий, то вероятность попадания удара в эту фразу очень низкая. Поэтому, несмотря на частые столкновения спортсменов и удары в область сердца в условиях тренировок и соревнований, случаи развития фрибрилляции желудочков после удара в грудную клетку встречаются редко.

У спортсменов при попадании удара в уязвимую фразу сердечного цикла развивается потеря сознания, происходит остановка сердца (падает артериальное давление, пропадает пульс, прекращается насосная функция сердца) и дыхания, зрачки неподвижны и расширены. Для исключения фратального исхода необходимо срочно оказать медицинскую помощь.

1. Убедиться, что после удара в область сердца произошла остановка сердца.

2. Немедленно начать кардиопульмональное оживление.

3. Своевременно провести дефибрилляцию сердца.

4. После оживления передать пострадавшего врачу скорой помощи и доставить его в кардиологический стационар.
Профрилактика внезапной сердечной смерти от сотрясений сердца направлена на обеспечение защиты грудной клетки спортсмена специальными средствами в контактных и игровых видах спорта. Необходимо следить, чтобы защитные средства были правильно расположены на грудной клетке с проекцией на сердце, а вероятность изменения их положения в процессе спортивной деятельности была бы минимальной.

После пережитого спортсменом сотрясения сердца вопрос о допуске к занятиям спортом решается после проведения лечебных, диагностических и реабилитационных мероприятий.

\section{Допинг}

Препараты допинга (стимуляторы, анаболические стероиды, психотропные средства, наркотики и т.д.) в значительной степени повышают риск внезапной сердечной смерти. Механизмы действия запрещенных препаратов на организм, и сердечно-сосудистую систему в частности, различны. Представим пример негативного влияния на деятельность сердечно-сосудистой системы анаболических стероидов, наиболее часто (40,1%) употребляемых как допинг [64].

Прием анаболических стероидов увеличивает мышечную массу, что способствует росту силы и скорости у представителей скоростно-силовых видов спорта, ускоряет восстановительный процесс за счет роста активности синтеза белков в мышцах у спортсменов в видах спорта на развитие выносливости. Такой механизм действия препаратов привлекает нечестных спортсменов к их использованию для повышения спортивных результатов. При использовании анаболических стероидов увеличивается мышечная масса не только скелетной мускулатуры, но и миокарда. Увеличение мышечной массы миокарда ведет к утолщению стенок левого желудочка сердца и межжелудочковой перегородки, что первоначально ведет к повышению производительности сердца. Однако при длительном применении анаболических стероидов происходит снижение систолической и диастолической функции желудочков сердца из-за развивающегося очагового фриброза, локального миокардита и гибели кардиомиоцитов в результате апоптоза [65]. При этом наблюдается снижение величины фрракции изгнания и уменьшение способности выполнять продолжительные динамические нагрузки [66].

Апоптоз, локальный миокардит и очаговый фриброз могут явиться причиной развития аритмий и блокад сердца различной локализации и степени выраженности, вплоть до несовместимых с жизнью. Продолжительное применение 
анаболических стероидов спортсменом ведет к развитию дилатационной кардиомиопатии, сопровождающейся снижением сократимости миокарда и развитием сердечной недостаточности $[65,67]$.

Прием анаболических стероидов оказывает влияние на обменные процессы организма, в результате которых резко снижается уровень холестерина высокой плотности, повышается уровень холестерина низкой плотности и триглицеридов, запуская механизм развития атеросклероза сосудов. Атеросклероз коронарных артерий у спортсменов на фоне высоких тренировочных и соревновательных нагрузок проявляется в виде ишемических реакций разной степени, вплоть до развития инфаркта миокарда $[68,69]$.

Негативное воздействие анаболических стероидов на миокард усиливается одновременным приемом препаратов с аналогичным механизмом

\section{Литература}

1. Buckley J. Physical activity in the prevention and management of atherosclerotic disease. In: IOC manual of sports cardiology. Ed.: Wilson M., Drezner J, Sharma S. Wiley \& Sons. Singapore. 2017: 53-61.

2. Mechanik J., Kushner R. Lifestyle medicine. 2016. Springer International Publishing AG. Switzerland.

3. Wienberger $\mathrm{H}$, Hambrecht R. Physical execise and its effects on coronary artery disease. Curr Opin Pharmacol. 2013; 13: 218-225.

4. Corrado D, Basso C, Pavel A, et al. Trends in sudden cardiovascular death in young competitive athletes after implementation of a preparticipation screening program. JAMA. 2006; 296: 1593-1601.

5. Van Camp S, Bloor C, Mueller F, et al. Nontraumatic sports death in high school and college athletes. Med Sci Sports Exerc. 1995 May; 27(5): 641-7.

6. Maron B. Sudden death in young athletes. N Engl J Med. 2003; 349: 1064-1075

7. Maron B, Doerer J, Haas T, et al. Sudden deaths in young competitive athletes: analyses of 1866 deaths in the United States, 1980-2006. Circulation. 2009; Mar 3: 119(8): 1085-92.

8. Corrado D, Pelliccia A, Bjornstad H, et al. Cardiovascular preparticipation screening of young competitive athletes for prevention of sudden death: proposal for a common European protocol. Eur Heart $J$. 2005; 26: 516-524.

9. Drezner J. Contemporary approaches to the identification of athletes at risk for sudden cardiac death. Curr Opin Cardiol. 2008; 23: 494501.

10. Wheeler M, Heidenreich P, Froelicher V, et al. Cost-effectiveness of preparticipation screening for prevention of sudden cardiac death in young athletes. Ann Intern Med. 2010; Mar 2; 152(5): 276-286.

11. Thiene G, Corrado D, Basso C. 2016. Sudden cardiac death in the young and athletes. Springer, Berlin.

12. Maron B. How should we screen competitive athletes for cardiovascular disease? Eur Heart J. 2005; 26: 428-30.

13. Pelliccia A, Fagard R, Bjornstad $H$, et al. Recommendations for competitive sports participation in athletes with cardiovascular disease: a consensus document from the Study Group of Sports Cardiology of the Working Group of Cardiac Rehabilitation and Exercise Physiology and the Working Group of Myocardial and Pericardial Diseases of the European Society of Cardiology. Eur Heart J. 2005; 26: 1422-45.

14. Chaitman B. An electrocardiogram should not be included in routine preparticipation screening of young athletes. Circulation. 2007; 27: 116(22), 2610-2614. действия (инсулиноподобного гормона роста), диуретиков (для сокрытия приема допинга), стимуляторов (ведущих к исчерпанию эндогенных энергетических ресурсов организма) и т.д. На таком фооне наличие в соревновательных условиях высокой спортивной конкуренции, неблагоприятных климатических фракторов (средне- или высокогорье, высокая температура и влажность воздуха и т.д.), проведение сгонки массы тела могут привести к трагическому исходу.

Заключение. Знания спортивного врача и его способность выявить начальные признаки патологии, ведущей к развитию внезапной сердечной смерти у спортсмена, провести лабораторные и инструментальные обследования, поставить диагноз лежат в основе выявления развития процесса на ранних стадиях, позволят успешно бороться с серьезной проблемой и сохранить жизнь спортсменов.

15. Le V, Wheeler M, Mandic S, et al. Addition of the electrocardiogram to the preparticipation examination of college athletes. Clin J Sport Med. 2010; 20: 98-105.

16. Pelliccia A, Corrado D. Cardiovascular screening for the prevention of sudden cardiac death in athletes. In: IOC manual of sports cardiology. Ed.: Wilson M, Drezner J, Sharma S. Wiley \& Sons. Singapore. 2017; 74-81.

17. Maron B, Doerer J, Haas T, et al. Sudden deaths in young competitive athletes: analyses of 1866 deaths in the United States, 1980-2006. Circulation. 2009; Mar 3: 119(8), 1085-1092.

18. Maron B, McKenna W, Danielson G, et al. American College of Cardiology/European Society of Cardiology clinical expert consensus document on hypertrophic cardiomyopathy. J Am Coll Cardiol. 2003 Nov 5; 42(9): 1687-713

19. Owens D. Hypertrophic cardiomyopathy. In: IOC manual of sports cardiology. Ed.: Wilson M, Drezner J, Sharma S. Wiley \& Sons. Singapore. 2017; 205-216.

20. Drezner J, Ashley E, Baggish A, et al. Abnormal electrocardiographic findings in athletes: recognising changes suggestive of cardiomyopathy. Br J Sports Med. 2013; 47: 137-152.

21. Maron B, Chaitman B, Ackerman M, et al. Recommendations for physical activity and recreational sports participation for young patients with genetic cardiovascular diseases. Circulation. 2004; 8: 109(22), 2807-2816

22. Antzelevitch C, Burashnikov A. Overview of basic mechanisms of cardiac arrhythmia. Card Electrophysiol Clin. 2011; 3(1): 23-45.

23. Rowin E, Maron B, Appelbaum E, et al. Significance of false negative electrocardiograms in prepartification screening of athletes for hypertrophic cardiomyopathy. Am J Cardiol. 2012 Oct 1; 110(7): 1027-32.

24. Uberoi $A$, Stein $R$, Perez $M$, et al. Interpretation of the electrocardiogram of young athletes. Circulation. 2011; 124: 746757.

25. Schnell F, Riding N, O'Hanlon R, et al. The recognition and significance of pathological T-wave inversions in athletes. Circulation. 2015; 131: 165-173.

26. Elliott $P$, et al. ESC guidelines on diagnosis and management of hypertrophic cardiomyopathy: the task force for the diagnosis and management of hypertrophic cardiomyopath. Eur Heart J. 2014; 35(39): 2733-79.

27. Chandra N, Bastiainen R, Papadakis M, Sharma S. Sudden cardiac death in young athletes. J Amer Coll Cardiol. 2013; 61: 10: 102740 . 
27. Lakdawala N, Thune J, Maron B, et al. Electrocardiografic features of sarcomere mutation carriers with and without clinically overt hypertrophic cardiomyopathy. Am J Cardiol. 2011; 108: 1606-13.

28. Kawasaki T, Sakai C, Harimoto K, et al. Usefulness of highsensitivity cardiac troponin $T$ and brain natriuretic peptide as biomarker of myocardial fibrosis in patient with hypertrophic cardiomyopathy. $\mathrm{Am} \mathrm{J}$ Cardiol. 2013; 112(6): 867-72.

29. Roncarati R, Viviani Alselmi C, Losi M, et al. Circulating miR$29 a$, among other up-regulated microRNAs, is the only biomarker for both hypertrophy and fibrosis in patient with hypertrophic cardiomyopathy. J Am Coll Cardiol 2014; 63(9): 920-27.

30. Basso C, Maron B, Corrado D, Thiene G. Clinical profile of congenital coronary artery anomalies with origin from the wrong aortic sinus leading to sudden death in young competitive athletes. J Am Coll Cardiol. 2000; 35: 1493-1501.

31. Maron B, Thomson P, Ackerman M, et al. Recomendation and consideration related to prepaticipation screening for cardiovascular abnormalities in competitive athletes. Circulation. 2007; 115: 1643-55. doi: 10.1161/CIRCULATIONAHA.107.181423

32. Davis J, Cerchin F, Jones T, Portman M. Major coronary artery anomalies in a pediatric population: incidence and clinical importance. J Am Coll Cardiol 2001; 37: 593-97.

33. Basso C, Thiene G. Congenital coronary artery anomalies. In: IOC manual of sports cardiology. Ed.: Wilson M, Drezner J, Sharma S. Wiley \& Sons. Singapore. 2017; 275-85.

34. Макарова ГА, Гуревич ТС, Ачкасов ЕЕ, Юрьев СЮ. Электрокардиограмма спортсмена: норма, патология и потенциально опасная зона []. «Спорт». Человек. Москва. 2018.

35. Chinenti C, Pieroni M, Frustaci A. Myocarditis: when to suspect and how to diagnose it in athletes. $J$ Cardiovascular Med. 2006; 7: 301-36.

36. Бойцов СА, Колос ИП, Лидов ПИ. и др. Национальные рекомендации по допуску спортсменов с отклонениями со стороны сердечно-сосудистой системы к тренировочно-соревновательному процессу. Рац. Фарм. Кардиол. 2011; 7 (приложение № 6).

37. Maron B, Zipes D. 36th Bethesda conference: Eligibility recommendation for competitive athletes with cardiovascular abnormalities. J Amer Coll Cardiol. 2005; 45 (8): 1313-15.

38. Thiene G, Corrado D, Basso C. Orphanet J Rare Diseas. 2007; 2:45. DOI: 10.1186/1750-1172-2-45

39. de Noroncha S, Sharma S, Papadakis M, et al. Aetiology of sudden cardiac death in athletes in the United Kingdom: a pathological study. Heart. 2009 Sep; 95(17):1409-14.

40. Basso C, Thiene G. Adipositas cordis, fatty infiltration of the right ventricle, and arrhythmogenic right ventricular cardiomyopathy. Just a matter of fat? Cardiovasc Pathol. 2005; 14(1):37-41.

41. Marcus F, et al. Diagnosis of arrhythmogenic right ventricular cardiomyopathy/dysplasia. Proposed modification of the task force criteria. Circulation 2010; 121(13):1533-41.

42. Saberniak J, Hasselberg N, Borgquist R, et al. Vigorous physical activity impairs myocardial function in patients with arrhythmogenic right ventricular cardiomyopathy-associated desmosomal mutation carriers. Eur J Heart Fail. 2014; 16(12): 1337-44.

43. Gemayal C, Pelliccia A, Thomson P. Arrhythmogenic right ventricular cardiomyopathy. J Am Coll Cardiol. 2001 Dec; 38(7): 1773-81.

44. Tsatsopoulou A, Pronotarios N, McKenna W. Arrhythmogenic right ventricular dysplasia, a cell adhesion cardiomyopathy: insights into disease pathogenesis from preliminary genotype-phenotype assessment. Heart. 2006; 92(12): 1720-23.

45. Basso C, Aguilera B, Banner J, et al. Guidelines for autopsy investigation of sudden cardiac death. Virchows Arch. 2008; 452(1): 11-18.

46. Бокерия ЛА, Бокерия ОЛ, Темирбулатова АШ. Аритмогенная дисплазия/кардиопатия правого желудочка. Анналы аритмологии. 2010; 3: 47-56.

46. Шубик ЮВ, Яшин СМ, Думписа ЯЮ. Аритмогенная дисплазия/кардиомиопатия правого желудочка. В кн.: Желудочковые аритмии. Бокерия ЛА, Ревишвили АШ, Ардашев АВ, Кочович ДЗ. Медпрактика. М. 2002; 78-99.

anatolilandor@gmail.com
47. Heidbüchtel H, Hoogsteen J, Fagard R, et al. High prevalence of right ventricular involvement endurance athletes with ventricular arrhythmias. Eur Heart J. 2003; 24: 1473-80.

48. Zorzi A, Corrado D. Arrhytmogenic ruight ventricular cardiomyopathy. In: IOC manual of sports cardiology. Ed.: Wilson M Drezner J, Sharma S. Wiley \& Sons. Singapore. 2017; 217-30.

49. Steriotis A, Bauce B, Daliento L, et al. Electrocardiographic pattern in arrhythmogenic right ventricular cardiomyopathy. Am J Cardio 2009; 103: 1302-08.

50. Zorzi A, EIMaghawry M, Rigato I. Exercise-induced normalization of right precordial negative T waves in arrhythmogenic right ventricular cardiomyopathy. Am J Cardiol. 2013; 112(3): 411-15

51. Pasotti M, Klersy C, Pilotto A, et al. Long-term outcome and risk stratification in dilated cardiomyopathies. J Am Coll Cardiol. 2008; 52: $1250-60$

52. Gati S, Sharma S. Dilated cardiomyopathy, left ventricular hypertrabeculation and noncompaction. In: IOC manual of sports cardiology. Ed.: Wilson M, Drezner J, Sharma S. Wiley \& Sons. Singapore. 2017: 231-39.

53. Goldberger A. A specific EKG triad associated with congestive heart failure. Pacing Clin Electrophysiol 1982; 5: 593-599.

54. Finocchiaro G, Papadakis M. Abnormal ECG finding in athletes: recognising changes suggestive of cardiomyopathy. In: IOC manual of sports cardiology. Ed.: Wilson M, Drezner J, Sharma S. Wiley \& Sons. Singapore. 2017: 104-113.

55. Pluim B, Zwinderman A, van der Laarse A, et al. The athlete's heart. A meta-analysis of cardiac structure and function. Circulation 1999: 100: 336-44.

56. Skalik R. Qualifying athletes for exercise. e-journal of the ESC Council. 2014; 12: 29.

57. Larsen $M$, et al. Sudden cardiac death in young adults: environmental risk factors and genetic aspects of premature atherosclerosis. J Forensic Sci. 2012; 57(3): 658-62.

58. Silvano A, de Noronha S, Sheppard M. Myocardial infarction with normal coronaries: an autopsy perspective. J Clin Pathol. 2013; 65: 512-16.

59. Swift D, Lavie C, Johannsen N, et al. Physical activity, cardiorespiratory fitness, and exercise training in primary and secondary coronary prevention. Circ J. 2013; 57: 347-55.

60. Шелия ГД. ЭКГ спортсменов, прекративших занятия спортом. Актуальные проблемы спортивной медицины: Материалы 24-ой Всесоюзной конфреренции по спортивной медицине. Москва. 1990: 169-172.

61. Maron B, Estes N. Commotio cordis. N Eng J Med. 2010; 362: 917-37.

62. Madias C. Link M. Commotio cordis. In: IOC manual of sports cardiology. Ed.: Wilson M, Drezner J, Sharma S. Wiley \& Sons. Singapore. 2017: 343-49.

63. Sheppard M. Causes of sudden death in sport: the impotance of autopsy and specialist examination of the heart. In: IOC manual of sports cardiology. Ed.: Wilson M, Drezner J, Sharma S. Wiley \& Sons. Singapore. 2017: 191-201.

64. Платонов ВН. (редактор) Допинг и эргогенные средства в спорте. Киев: Олимп. лит. 2003.

65. Ahlgrim C, Guglin M. Anabolics and cardiomyopathy in a bodybuilder: case report and literature review. J Cardiol Failure. 2009; 15: 6, 496-500

66. Sheikh N, Papadakis M, Carre F, et al. Cardiac adaptation to exercise in adolescent athletes of African ethnicity: an emergent elite athletic population. Br J Sports Med. 2013; 49(9): 585-92.

67. Montisci M, et al. Anabolic androgenic steroids abuse and cardiac death in athletes: morphological and toxicological findings in four fatal cases. Forensic Sci Int. 2012; 217(1-3): 13-18.

68. Godon P, Bonnefoy E, Guérard S. Myocardial infarction and anabolic steroid use. A case report. Arch Mal Coeur Vais. 2000; 93: 879-83.

69. Halvorsen S, Thorsby P, Haug E. Acute myocardial infarction in a young man who had been using androgenic anabolic steroids. Tidsskr Nor Laegeforen. 2004; 124: 170-2.

Надійшла 21.02.2020 